\title{
Annual Report of Whooping Cranes in Saskatchewan, 1958
}

By F. G. Bard, Saskatchewan Museum of Natural History.

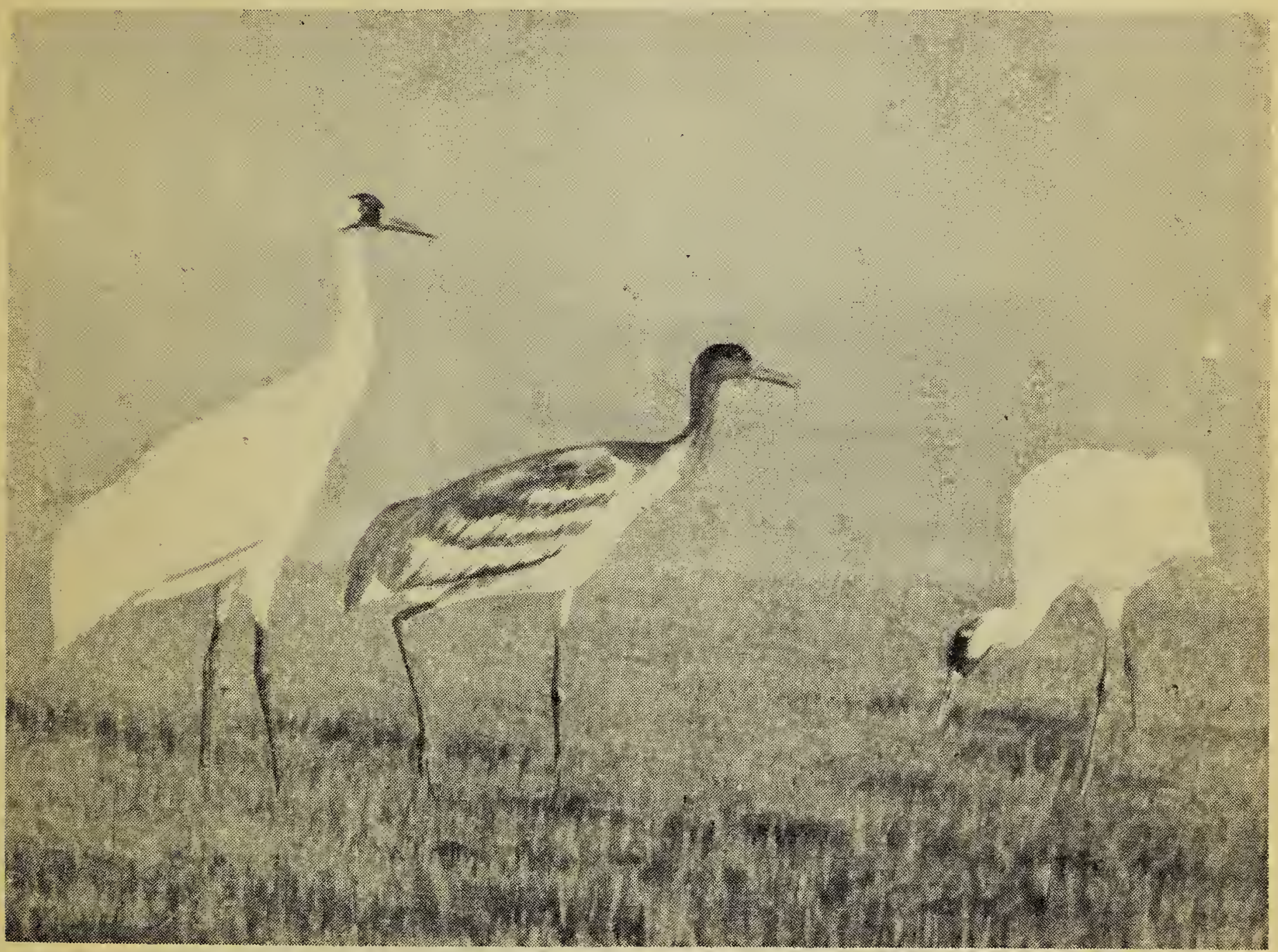

Painting by F.W. Lahrman, 1959

Although three adult birds failed to return to the Aransas Refuge last fall, the Whooping Crane picture has been brightened by the increase in the number of young in 1958. Nine ycung and 23 adultis made up the aerial count of 32 reported in the letter of Dec. 5, 1958, from Claude F. Lard, Refuge Manager at the Aransas National Wildlife Refuge. The nine young raised in the wild and one raised by the captive pair at New Orleans make a total of ten young for 1958-giving a great lift to the Whooping Crane population.

The New Orleans pair raised only one young this past year. Counting the two young raised previously, the New Orleans flock now stands at five. A single bird in San Antonio brings the number of captive birds to six, which with the wild fiock of 32 establishes a grand total of 38 birds. Without the loss of the three adults which failed to return last fall, we should have had 4.1 birds- a $25 \%$ increase over 1957 !

Generally speaking the Whooping Cranes are not as well off for cover as they were a year ago. The very poor run-off and low rainfall of 1958 have had a disastrous effect on our surface waters. This may bring whoopers into areas where we can expect heavier gun pressure. As it is, there is always the risk of a crane being shot along the flyway through error or carelessness. Erach fall a number of immaiture Whistling Swans are shot for geese, and this year several of our banded Pelicans were shot during the hunting season! Because whoopers are continually in similar danger I never cease to marvel how such a small flock of them can run the gauntlet of hazards along the flyway, and yet arrive safely each year in Aransas! 
Spring, summer and fall records of Whooping Cranes in Saskatchewan in 1958 are shown in the following tables. The spring records below

\begin{tabular}{lr|c|l}
\hline \multicolumn{3}{c}{ Table I-Spring Records, 1958 } \\
\hline Date & No. Birds & Place \\
\hline April & 8 & 3 & Govan \\
April & 13 & 3 & Arbury \\
April 17 & 3 & Katepwa Beach \\
April 19 & 3 & Penn \\
April & 21 & 3 & Blaine Lake \\
April & 25 & 5 & Pierceland \\
April & 27 & 2 & Benson \\
May & $6-30$ & 1 & Simpson (east) \\
\hline
\end{tabular}

Table II-Summer Wanderers, 1958

\begin{tabular}{l|c|l}
\hline Date & No. Birds & Place \\
\hline May 6, 27, 30 & 1 & Simpson \\
Aug. 24, 28 & & \\
Sept. 3, 8, 28 & 1 & Imperial \\
Sept. 10, 24, 25 & 1 & Dafoe- \\
Kandahar \\
Sept. 29 & 29 & Kandahar \\
Sept. 30 & 1 & Wadena \\
\hline
\end{tabular}

\begin{tabular}{|c|c|c|}
\hline \multicolumn{3}{|c|}{ III-Fall Records, } \\
\hline Date & No. Birds & Place \\
\hline Sept. $30 *$ & 3 & Imperial \\
\hline Oct. 1 & 2 ad. & Imperial \\
\hline Oct. 1,28 & 2 ad. & $\begin{array}{l}\text { Last. Mt. Lake } \\
\text { (north end) }\end{array}$ \\
\hline Oct. 2 & 1 ad. & Imperial \\
\hline Oct. 2 & 1 ad. & Govan \\
\hline Oct. 3 & $\begin{array}{ll}2 & \text { ad. } \\
2 & \text { yg. }\end{array}$ & Ceepee \\
\hline Oct. 5 & $\begin{array}{ll}2 & \text { ad. } \\
1 & \text { yg. }\end{array}$ & Khedive \\
\hline Oct. $5,6,8$ & 1 ad. & Elfros \\
\hline Oct. 6 & 1 ad. & Wadena \\
\hline Oct. 6 & $1+1$ & Gibbs \\
\hline Oct. 10 & 1 & Creelman \\
\hline Oct. 11 & 1 & Corning \\
\hline Oct. 12 & 2 ad. & $\begin{array}{l}\text { Richard } \\
\text { (North } \\
\text { Battleford) }\end{array}$ \\
\hline Oct. 12 & $\begin{array}{l}2 \\
2\end{array}$ & $\begin{array}{l}\text { Strasbourg } \\
\text { Lajord }\end{array}$ \\
\hline Oct. 13 & 2 ad. & Weyburn \\
\hline Oct. 15 & $\begin{array}{ll}2 & \text { ad. } \\
2 & \text { yg. }\end{array}$ & $\begin{array}{l}\text { Buffalo Pound } \\
\text { Lake }\end{array}$ \\
\hline Oct. 15 & 2 ad & Govan \\
\hline Oct. 17,19 & 2 ad. & Cymric \\
\hline Oct. 21,28 & $\begin{array}{l}2 \text { ad. } \\
2 \\
\text { yg. }\end{array}$ & Langham \\
\hline Oct. 22 & 2 ad. & Govan (west) \\
\hline Oct. 25 & 2 ad. & Strasbourg \\
\hline Oct. 26-31 & 2 ad. & Cymric \\
\hline
\end{tabular}

* It is difficult to separate summer wanderers from migrants, but the fall migration was thought to begin on September 30 at Imperial. were not all field checked, but they all fall within the known area (except Blaine Lake).

From the summary of reports and of field checks made by Fred Lahrman, it appears that 19 Whooping Cranes ( 15 adults and 4 young) were cibserved in the province in 1958.

Observers who watch for Whooping Cranes in fall migration will be interested in knowing when these birds come into the fields to feed. The regularity of feeding times is shown in the following observations: Morning feeding-arrival 6.50 to 7.15 a.m., departure 9.15 to 9.47 a.m.; Afternoon feeding-arrival 3.30 to 3.40 p.m., departure 5.04 to 5.07 p.m. However, in 11 observations unusual afternoon arrivals were noted at 1.45 and 2.30 p.m., and unusual departures at 1.20 and $4.40^{\circ}$ p.m. The bird observed leaving the field at the unusual hour of 1.20 p.m. had not been seen arriving. "the reason for this irregularity was not evident as the birds did not seem to have been disturbed by hunters (in spite of the heavy hunting pressure in the Last Mountain Lake region).

On October 15, two Regina hunters, H. Martz and E. Morris, saw two Whooping Cranes feeding west of Govan near the lake. Nearby they

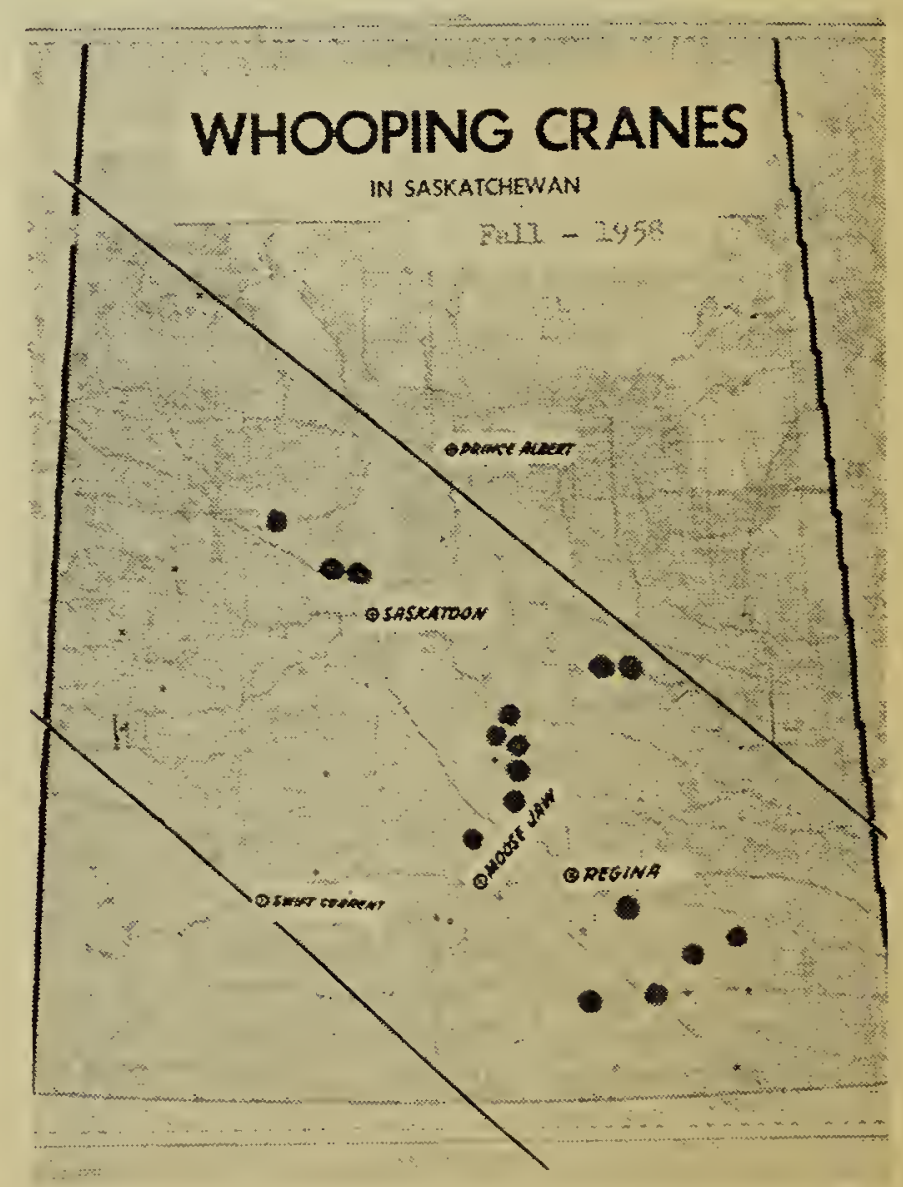

Sask. Gov't. Photo

WHOOPING CRANES IN ${ }^{*}$ SASK., FALL 1958 


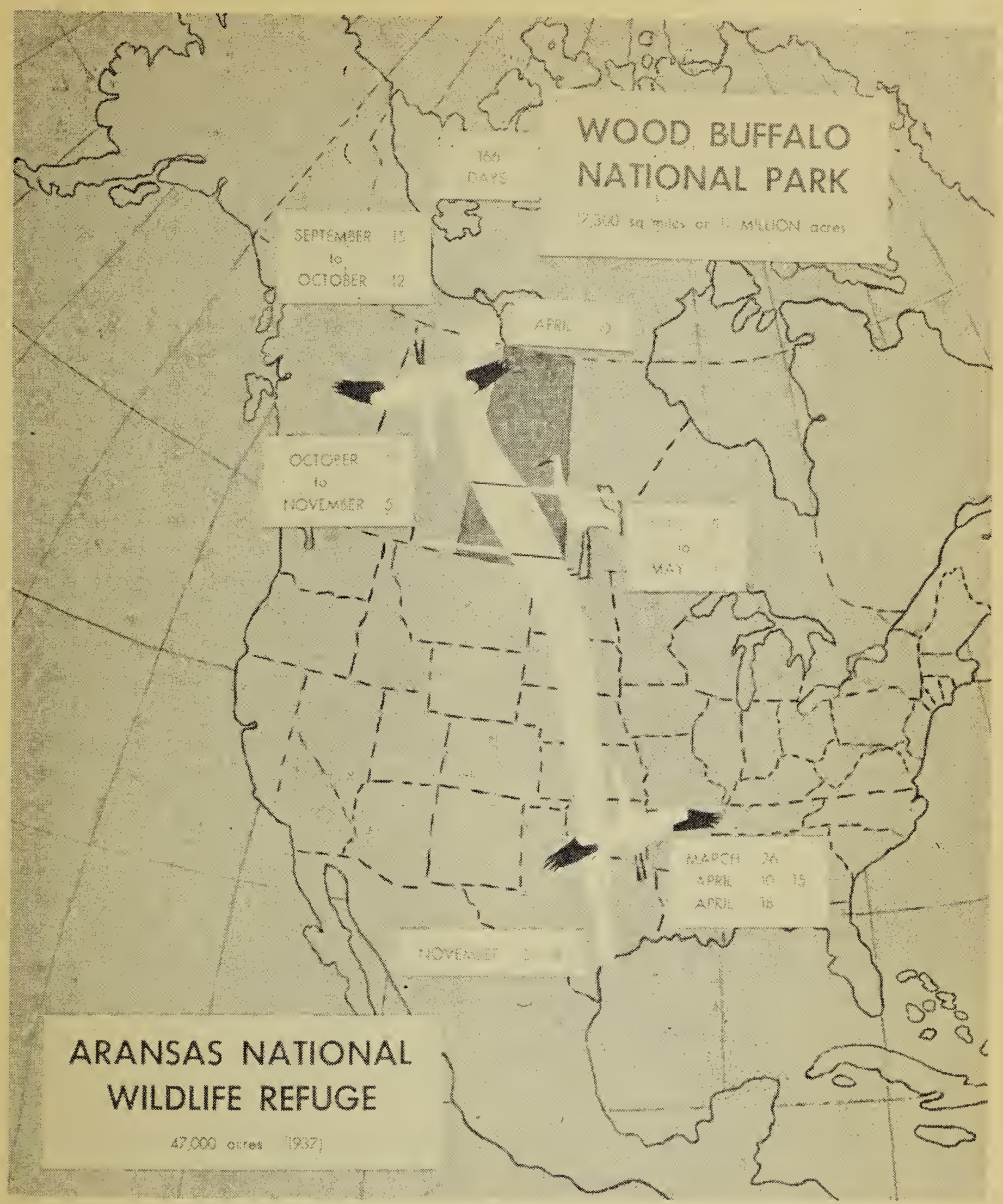

Sask. Govt. Photo

AVERAGE DATES FOR MIGRATION AND APPEARANCES

noticed a country school and decided to report their find for the benefit of the teacher and students. With the use of binoculars each pupil had an opportunity of observing these rare and wonderful birds. The teacher was delighted, for that very morning the class had been discussing the Whooping Crane. Our special thanks to these sportsmen for their educacational and considerate act.

I should like to acknowledge further reports of birds that may have been Whosping Cranes. Some of these came from areas outside our present established boundaries, and we must therefore omit these reports until they are corroborated. We nevertheless wish to convey our thanks to the many observers; with your help we shall add new areas to our records. Two-thirds of the records printed above were fieldchecked; the cthers have been accepted because they were associated with field-checked records. 